\title{
A specifikus IgM- és IgG-antitesteket detektáló gyorstesztek értéke a SARS CoV-2 vírusfertőzés kimutatásában
}

\author{
Vásárhelyi Barna dr. ${ }^{1}$ - Kristóf Katalin dr. ${ }^{1}$ - Ostorházi Eszter dr. ${ }^{2}$ \\ Szabó Dóra dr. ${ }^{2}$ - Prohászka Zoltán dr. ${ }^{3}$ - Merkely Béla dr. ${ }^{4}$ \\ ${ }^{1}$ Semmelweis Egyetem, Általános Orvostudományi Kar, Laboratóriumi Medicina Intézet, Budapest \\ ${ }^{2}$ Semmelweis Egyetem, Általános Orvostudományi Kar, Orvosi Mikrobiológiai Intézet, Budapest \\ ${ }^{3}$ Semmelweis Egyetem, Általános Orvostudományi Kar, III. Belgyógyászati Klinika, Kutatólaboratórium, \\ Budapest \\ ${ }^{4}$ Semmelweis Egyetem, Rektori Hivatal, Budapest
}

\begin{abstract}
Bevezetés: 2020. március végén a SARS-CoV-2-vírusfertőzöttség (COVID-19-betegség) diagnosztizálására megjelentek Magyarországon a vírussal szembeni specifikus antitestek jelenlétét kimutató gyorstesztek.

Célkitüzés: Munkánkban két gyorsteszt, az Anhui és a Clungene teszt diagnosztikai teljesítményét értékeltük a fertőzés kimutatásában arany standardnak számító 'real-time' (valós idejű) PCR (a továbbiakban: PCR) vizsgálati eredmények alapján.

Módszer: 2020. március 16. és április 14. között intézetünk 20 120, COVID-19-fertőzéssel kapcsolatos rekordot küldött be az országos adatszolgáltató rendszeren keresztül. Ebben 4140 személynél csak IgM és IgG jelenlétét kimutató gyorstesztvizsgálat történt; 3210 személynél csak PCR-teszt, 1654 személynél pedig PCR- és gyorstesztvizsgálat (Anhui: 625, Clungene: 1029) végzésére maximum 3 nap eltéréssel is sor került. PCR-pozitívnak azt a személyt tekintettük, akinél bármikor PCR-pozitivitás fordult elő, illetve antitestpozitívnak azt, akinél IgM- és/vagy IgGpozitivitást észleltünk. (Megjegyzés: a Clungene tesztet Lungene néven is forgalmazzák.)

Eredmények: A 4864, PCR-rel vizsgált személy közül 308 volt PCR-pozitív (a PCR-pozitivitás prevalenciája 6,3\% volt). A PCR alapján az Anhui gyorsteszt szenzitivitása 33,3\%, specificitása 72,85\%; a Clungene gyorsteszt szenzitivitása $35,48 \%$, specificitása $85,02 \%$ volt. $6 \%$-os PCR-pozitivitási prevalencia esetén a pozitív és a negatív prediktív érték az Anhui gyorsteszt esetében 7,28\%, illetve 94,48\%, míg a Clungene gyorsteszt esetében 13,13\%, illetve 95,38\% volt. Következtetés: Az aktuális fertőzöttségi prevalencia melletti alacsony pozitív prediktív értékek alapján az általunk értékelt gyorstesztek jelenleg nem alkalmasak a SARS-CoV-2-vírusfertőzöttség (PCR-pozitivitás) kimutatására az általános populációban. Az Anhui és a Clungene gyorstesztek negatív eredményei a jelenlegi 6\%-os prevalencia mellett mintegy 95\%-os valószínúséggel jelzik a SARS-CoV-2-vírusexpozíció hiányát. Az Anhui és a Clungene - SARSCoV-2 vírus elleni IgM- és IgG-antitesteket kimutató - gyorstesztek alkalmazása a COVID-19-fertőzés differenciáldiagnosztikájában szakmailag vállalhatatlan.

Orv Hetil. 2020; 161(20): 807-812.
\end{abstract}

Kulcsszavak: COVID-19-pandémia, SARS-CoV-2 vírus, gyorsteszt, 'real-time' PCR

\section{The diagnostic value of rapid anti $\operatorname{IgM}$ and IgG detecting tests} in the identification of patients with SARS CoV-2 virus infection

Introduction: At the end of March, 2020, rapid tests detecting the presence of antiviral $\operatorname{IgM}$ and $\operatorname{IgG}$ antibodies against SARS-CoV-2 virus were introduced in Hungary for the identification of SARS-CoV-2 infection (COVID-19 disease).

Aim: We evaluated two rapid tests (Anhui and Clungene) in comparison with those of real-time PCR tests considered as the gold standard in the detection of infection. 
Method: Between 16, March and 14, April, 2020, we performed rapid IgM and IgG detecting tests without PCR; PCR without rapid tests; and PCR WITH rapid tests in 4140, 3210 and 1654 patients, respectively. (Out of these 1654 patients, Anhui and Clungene tests were used for testing in 625 and 1029 patients, respectively.) Patients were considered as positive in PCR and rapid tests when PCR positivity and IgM or IgG positivity occurred at any time, respectively. (Note: Clungene test is also marketed as 'Lungene'.)

Results: The prevalence of PCR positivity in 4864 patients tested with PCR was $6.3 \%$. The sensitivity and specificity of Anhui and Clungene tests were $33.3 \%$ and $72.85 \%$, and $35.48 \%$ and $85.02 \%$, respectively. At $6 \%$ PCR positivity, the positive and negative predictive values of Anhui and Clungene were $7.28 \%, 94.48 \%, 13.13 \%$, and $95.38 \%$, respectively.

Conclusion: The low positive predictive values indicate that Anhui and Clungene rapid tests detecting the presence of anti-IgM and anti-IgG against SARS-CoV-2 virus infection are not suitable for screening SARS-CoV-2 vírus infection in the general population. These results strongly support that Anhui and Clungene rapid tests detecting IgM and IgG antibodies against SARS-CoV-2 virus should not be used in the differential diagnosis of infection.

Keywords: COVID-19 pandemia, SARS-CoV-2 novel coronavirus, rapid tests, real-time PCR

Vásárhelyi B, Kristóf K, Ostorházi E, Szabó D, Prohászka Z, Merkely B. [The diagnostic value of rapid anti IgM and IgG detecting tests in the identification of patients with SARS CoV-2 virus infection]. Orv Hetil. 2020; 161(20): 807-812.

(Beérkezett: 2020. április 17.; elfogadva: 2020. április 19.)

\begin{abstract}
Rövidítések
$\mathrm{C}=$ kontroll $; \mathrm{CE}=($ Conformité Européenne $)$ európai megfelelőség; COVID-19 = (coronavirus disease 2019) koronavírusbetegség 2019; IgG = immunglobulin-G; IgM = immunglobulin-M; IVD = in vitro diagnosztika; $\mathrm{PCR}=$ (polymerase chain reaction) polimeráz-láncreakció; $\mathrm{PPV}=$ pozitív prediktív érték; RNS = ribonukleinsav; SARS-CoV-2 = (severe acute respiratory syndrome coronavirus 2) súlyos akut légúti tünetegyüttest okozó koronavírus-2; taj = társadalombiztosítási azonosító jel; VTM = vírustranszport-médium
\end{abstract}

A SARS-CoV-2-vírusfertőzés laboratóriumi kimutatására Magyarországon a klinikai gyakorlat számára két lehetôség van.

Arany standard a vírus örökítőanyagának kimutatása ún. valós idejű, vagy 'real-time' polimeráz-láncreakcióval [1] (a továbbiakban: PCR). Az eljárás szakaszai az RNS kivonása a légúti (alsó légúti vagy orr- és garat-) mintából, ennek amplifikálása PCR-módszerrel és az amplifikáció valós idejű kimutatása [2]. Ez a folyamat a ma rutinszerűen Magyarországon használt módszerekkel több órán át tart. A vírus közvetlen kimutatása eszköz-, szaktudás- és munkaigényes. A módszer további korlátja, hogy - mivel világszerte kiterjedten ezzel mutatják ki a vírust - a reagens- és fogyóanyag-gyártó cégek aktuálisan nem mindig tudnak időben reagenst szállítani. Egy vizsgálat önköltségi ára kb. 20 ezer Ft. (Szintén a vírus RNSét mutatják ki molekuláris biológiai módszerekkel egyes, betegágy melletti rendszerek [3]. Ezeket a teszteket jelenleg dinamikusan fejlesztik, az általános gyakorlatba még nem kerültek be.)

Világszerte széles körben alkalmaznak szerológiai gyorsteszteket, amelyek vérmintában mutatják ki a vírussal szemben a szervezetben képződött SARS-CoV-2 vírusra specifikus, IgM- és IgG-típusú ellenanyagokat.
Ezek jellemzően 'lateral flow immunoassay' tesztek, melyek előnye, hogy használatukhoz nem kell különösebb szaktudás, az eredmény 15 percen belül rendelkezésre áll. Önköltségi áruk $5000 \mathrm{Ft}$ alatt van. Korlátjuk, hogy az antitestek megjelenéséig tartó, kb. 5-7 napos ablakperiódusban nem jelzik a fertőzést, negatív eredményt adnak [4], és nem elhanyagolható mértékben szolgáltathatnak álpozitív eredményt (például keresztreakció más infekció vagy gyulladásos válaszreakció miatt).

Az aktuálisan zajló COVID-19-járvány kapcsán több, döntően kínai vállalat kezdett el nagy mennyiségben forgalmazni antitest-kimutatásra való gyorsteszteket. A gyorstesztek diagnosztikai értékére, a PCR-rel kimutatott eredményhez való viszonyukra, illetve az eredmények értékelését zavaró tényezőkre vonatkozóan csak nagyon kevés, kizárólag ázsiai mintán szerzett információ áll rendelkezésre.

Munkánk során azt a célt tűztük ki, hogy összevessük a laboratóriumunkban 2020. március 28. és április 14 . között COVID-19-fertőzés kimutatására elvégzett gyorstesztvizsgálatok eredményét a PCR-vizsgálatok eredményével, és megállapítsuk a gyorstesztek diagnosztikai értékét COVID-19-fertőzésben.

\section{Betegek és módszer}

A vizsgálati minták a vizsgálati időszakban a Semmelweis Egyetem dolgozóitól, az itt kezelt betegektől, valamint fóvárosi, illetve Pest megyei és Fejér megyei egészségügyi intézményekben dolgozó vagy ott kezelt személyektől érkeztek laboratóriumunkba.

A PCR-hez a légúti mintát transzportközeget tartalmazó VTM- (vírustranszport-médium) csőbe vették le, melyet 24 órán belül eljuttattak laboratóriumunkba. A tárolás és a szállítás $4-6{ }^{\circ} \mathrm{C}$-on történt. 
Az RNS-kivonáshoz és a 'real-time' PCR-amplifikációhoz szükséges reagensek kereskedelmi forgalomban kapható CE-IVD minősítésúek voltak. Az amplifikálási és detektálási lépések LightCycler 480 készüléken (Roche, Bázel, Svájc) történtek. Pozitívnak akkor tekintettünk egy mintát, ha kevesebb, mint 39 ciklusszámon belül jellegzetes amplifikáció következett be mindkét vírusspecifikus mérési csatornán. Negatívnak akkor tekintettünk egy mintát, ha vírusspecifikus amplifikáció nem következett be, és az RNS integritását jelző belső kontroll pozitív jelet adott. Minden egyes futtatás során pozitív és negatív kontroll alkalmazására is sor került. Logisztikai problémák miatt a folyamat során a PCR-vizsgálat egyes elemeihez felhasznált reagensek gyártói, beszállítói változtak. (Kérésre a mérési jegyzőkönyveket és a pontos reagensspecifikációkat a járvány vége után az érdeklődők számára betekintésre megmutatjuk.)

Laboratóriumunkban kétféle gyorsteszt alkalmazására került sor: 2020. március 28. és április 2. között Anhui (gyártó: Anhui Deep Blue Medical Technology Co., Ltd., Kína), ezt követően Clungene (Lungene néven is forgalmazott) (gyártó: Hangzhou Clongene Biotech Co., Ltd., Kína) típusú, SARS-CoV-2-specifikus IgM és IgG kimutatására alkalmas kitet használtunk. A méréshez natív vérből nyert szérumot használtunk. Mindkét teszt esetében a múanyag lapocskán lévő vájulatba cseppentettünk 10 mikroliter szérumot, majd 2 csepp (5070 mikroliter) puffer hozzáadása után a tesztmezőben megjelenő csíkok alapján olvastuk le, jelen van-e a szervezetben specifikus IgM- és/vagy IgG-izotípusú ellenanyag. A teszt eredményét akkor fogadtuk el validnak, ha a kontroll (C)-csík megjelent: látható kontrollcsík esetén az IgM-mezőben megjelenő bármilyen erősségü csík esetén SARS-CoV-2 elleni anti-IgM, az IgG-mezőben megjelenő bármilyen erősségű csík esetén SARS-CoV-2 elleni anti-IgG jelenlétét állapítottuk meg.

Egyeseknél több alkalommal is történt PCR-vizsgálat. Ha ezekből bármelyik PCR-eredmény pozitív volt, akkor azt a beteget PCR-pozitívnak tartottuk.

Több személynél több alkalommal történt gyorstesztvizsgálat. Ezek eredményei közül az első alkalommal kapott eredményt használtuk. Pozitívként soroltuk be a személyt akkor, ha akár IgM-, akár IgG-pozitivitást jelzett a gyorsteszt.

A személyek azonosítását taj szám alapján egy munkatárs (V. B.) végezte, a társítást követően az azonosítókat irreverzibilisen törölte.

A gyorstesztek diagnosztikai teljesítőképességét a PCR-eredményekhez (fertőzóképesség) viszonyítottuk. A PCR alapján valós pozitív és valós negatív, illetve álpozitív és álnegatív eredmények száma alapján meghatároztuk a gyorsteszt szenzitivitását és specificitását. Emellett különböző teoretikus prevalenciaértékek esetében kiszámoltuk a gyorsteszt adjusztált pozitív és negatív prediktív értékét a világhálón elérhető segédeszközzel [5].
1. táblázat A SARS-CoV-2 elleni IgM-et és IgG-t kimutató Anhui és Clun gene gyorstesztek eredményeinek és a vírusnukleinsav direkt kimutatását végző 'real-time' PCR-eredményeknek az összehasonlítása

\begin{tabular}{lcc}
\hline Anhui gyorsteszt & PCR-negatív & PCR-pozitív \\
\hline IgM-negatív, IgG-negatív & 440 & 14 \\
IgM-pozitív, IgG-negatív & 92 & 5 \\
IgG-pozitív, IgM-negatív & 10 & 0 \\
IgM-pozitív, IgG-pozitív & 62 & 2 \\
\hline Összes mérés & 604 & 21 \\
\hline & & 20 \\
\hline Clungene gyorsteszt & PCR-negatív & PCR-pozitív \\
\hline IgM-negatív, IgG-negatív & 840 & 2 \\
IgM-pozitív, IgG-negatív & 88 & 4 \\
IgG-pozitív, IgM-negatív & 44 & 5 \\
IgM-pozitív, IgG-pozitív & 26 & 31 \\
\hline Összes mérés & 998 &
\end{tabular}

Megjegyzés: Egyeseknél több alkalommal is történt PCR-vizsgálat. Ha ezekből bármelyik PCR-eredmény pozitív volt, akkor azt PCR-pozitívnak tartottuk.

IgG = immunglobulin-G; IgM = immunglobulin-M; PCR = polimeráz-láncreakció; SARS-CoV-2 = súlyos akut légúti tünetegyüttest okozó koronavírus-2

\section{Eredmények}

A vizsgált időszakban 20120 rekord került beküldésre a laboratóriumi mikrobiológiai informatikai rendszeren keresztül. Egy rekord egy személyhez rendelve egy eredményt tartalmaz. (Minden egyes PCR- vagy IgM- vagy IgG-eredmény külön rekordon jelenik meg.)

A vizsgált rekordok alapján 4140 személynél csak IgM és IgG jelenlétét kimutató gyorstesztvizsgálat történt; 3210 személynél csak PCR-vizsgálat, 1654 személynél pedig PCR- és gyorstesztvizsgálat (Anhui: 625, Clungene: 1029) végzésére maximum 3 nap eltéréssel is sor került.

A gyorsteszt- és a PCR-eredményeket az Anhui, illetve a Clungene tesztek esetében az 1. táblázat mutatja.

A PCR-eredményekhez viszonyított gyorsteszt-szenzitivitási, -specificitási értékeket, illetve a SARS-CoV2 -vírusfertőzés egyes becsült prevalenciaértékei melletti pozitív és negatív prediktív értékeket a 2. táblázat öszszegzi. Összességében megállapítható, hogy az aktuális hazai vírusfertőzöttségi prevalenciaérték melletti pozitív prediktív értékek rendkívül alacsonyak mindkét gyorsteszt esetén, és ezt a hátrányt az sem kompenzálja, hogy a negatív prediktív értékek $90 \%$ felettiek.

A 2. táblázatban az is látható, hogy az Anhui és Clungene tesztek szenzitivitása és specificitása nagyon alacsony (33\%, illetve $35 \%$ és $73 \%$, illetve $85 \%$ ).

Laboratóriumunkban a 4864, PCR-rel vizsgált összes személy közül 308 volt PCR-pozitív (a PCR-pozitivitás prevalenciája 6,3\% volt). Az 1654, PCR-rel és gyors- 
Az Anhui és a Clungene tesztekkel észlelt, SARS-CoV-2 elleni IgM- és/vagy IgG-pozitivitás prediktív értéke PCR-pozitivitásra

Az Anhui teszt esetében

\begin{tabular}{lcc}
\hline Számolt paraméter & Érték & $\begin{array}{c}\text { 95\%-os megbízhatósági } \\
\text { tartomány }\end{array}$ \\
\hline Szenzitivitás & $33,33 \%$ & $14,59-56,97 \%$ \\
Specificitás & $72,85 \%$ & $69,11-76,36 \%$ \\
Prevalencia: 6\% & \\
Pozitív prediktív érték & $7,27 \%$ & $4,05-12,70 \%$ \\
Negatív prediktív érték & $94,48 \%$ & $92,65-95,88 \%$ \\
Prevalencia: 2\% & & \\
Pozitív prediktív érték & $2,44 \%$ & $1,33-4,45 \%$ \\
Negatív prediktív érték & $98,17 \%$ & $97,53-98,64 \%$ \\
Prevalencia: 10\% & & \\
Pozitív prediktív érték & $12,00 \%$ & $6,84-20,21 \%$ \\
Negatív prediktív érték & $90,77 \%$ & $87,86-93,04 \%$ \\
Prevalencia: 30\% & & \\
Pozitív prediktív érték & $34,47 \%$ & $22,08-49,42 \%$ \\
Negatív prediktív érték & $71,83 \%$ & $65,24-77,60 \%$ \\
\hline
\end{tabular}

A Clungene teszt esetében

\begin{tabular}{lcc}
\hline Számolt paraméter & Érték & $\begin{array}{c}\text { 95\%-os megbízhatósági } \\
\text { tartomány }\end{array}$ \\
\hline Szenzitivitás & $35,48 \%$ & $19,23-54,63 \%$ \\
Specificitás & $85,02 \%$ & $82,64-87,19 \%$ \\
Prevalencia: 6\% & \\
Pozitív prediktív érték & $13,13 \%$ & $8,42-19,91 \%$ \\
Negatív prediktív érték & $95,38 \%$ & $94,08-96,41 \%$ \\
Prevalencia: $2 \%$ & \\
Pozitív prediktív érték & $4,61 \%$ & $2,86-7,36 \%$ \\
Negatív prediktív érték & $98,47 \%$ & $98,03-98,82 \%$ \\
Prevalencia: 10\% & & \\
Pozitív prediktív érték & $20,84 \%$ & $13,80-30,21 \%$ \\
Negatív prediktív érték & $92,22 \%$ & $90,12-93,91 \%$ \\
Prevalencia: 30\% & & \\
Pozitív prediktív érték & $50,38 \%$ & $38,17-62,54 \%$ \\
Negatív prediktív érték & $75,46 \%$ & $70,28-79,99 \%$ \\
\hline
\end{tabular}

IgG = immunglobulin-G; IgM = immunglobulin-M; PCR = polimeráz-láncreakció; SARS-CoV-2 = súlyos akut légúti tünetegyüttest okozó koronavírus-2

teszttel is vizsgált beteg esetében ugyanez az arány 3,1\% volt.

6\%-os PCR-pozitivitás mellett az Anhui teszt pozitív és negatív prediktív értéke $<10 \%$, illetve $94,48 \%$. A Clungene teszt esetében ugyanezek az értékek 13\%, illetve $95,38 \%$.

Az Anhui és a Clungene tesztek esetében az egyes prevalenciaértékek mellett számolt pozitív és negatív prediktív értékeket és konfidenciaintervallumokat az 1. ábra összegzi.
Anhui

Clungene
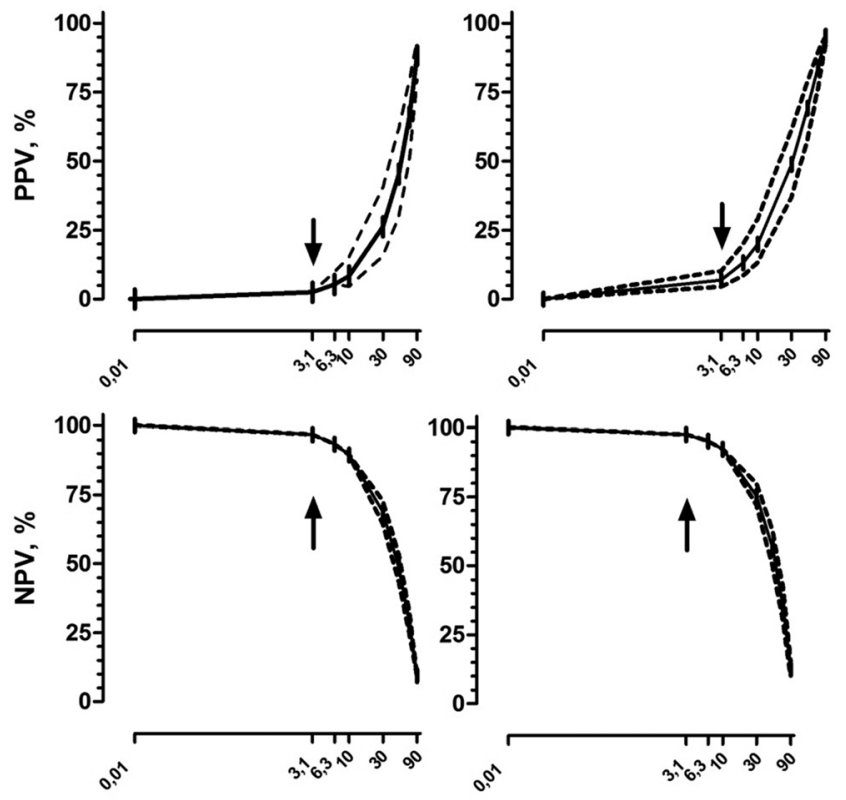

SARS-CoV-2-fertőzés, prevalencia (\%) (logaritmikus skála)

1. ábra

A SARS-CoV-2 elleni $\mathrm{IgM} / \mathrm{IgG}-\mathrm{t}$ kimutato gy tív és pozitív predikciós értéke a 'real-time' PCR-negativitásra és -pozitivitásra a fertőzés prevalenciájának függvényében

A SARS-CoV-2 hazai populációs prevalenciáját (1652/10 millió, kerekítve $0,01 \%$ ) a 2020 . április 16-án a koronavirus.gov.hu honlapon közölt adatok alapján számítottuk; a vizsgálatunk során elemzett mintáink adatai alapján számolt prevalenciaadatok 3,1\%-nak és 6,2\%-nak adódtak (a részleteket ld. a szövegben); a prediktív értékek változásának modellezésére ábrázoltuk a $10 \%$, $30 \%, 50 \%, 70 \%$ és $90 \%$ hipotetikus prevalencia mellett várható értékeket is. A negatív prediktív érték (NPV) ebben az esetben a következő kérdést válaszolja meg: a gyorsteszt negatív (IgM- és IgG-) eredménye milyen arányban tartozik PCR-negatív (nem fertőzóképes) személyhez? A pozitív prediktív érték (PPV) ebben az esetben a következő kérdést válaszolja meg: a gyorsteszt pozitív (IgM- és/vagy IgG-) eredménye milyen arányban tartozik PCR-pozitív (fertőzóképes) személyhez? (A cikkben bemutatott és elemzett vizsgálati mintába (1654 fó) azok a személyek kerültek be, akiknél a gyorsteszt végzéséhez képest maximum 3 nap eltéréssel került sor a PCR teszt elvégzésére)

IgG = immunglobulin- $\mathrm{G} ; \operatorname{Ig} M=$ immunglobulin- $\mathrm{M} ; \mathrm{NPV}=$ negatív prediktív érték; $\mathrm{PCR}=$ polimeráz-láncreakció; $\mathrm{PPV}=$ pozitív prediktív érték; SARS-CoV-2 = súlyos akut légúti tünetegyüttest okozó koronavírus-2

\section{Megbeszélés}

A SARS-CoV-2-vírusfertőzöttség és -fertőzőképesség kimutatása járványügyi szempontból kiemelkedő jelentőségű. Az érintett személyek izolálása segíthet késleltetni a járvány terjedését [1].

A fertőzőképesség kimutatására egyértelmű választ adhat a vírusnukleinsav és/vagy -antigének kimutatása. A vírusantigének szerológiai kimutatására intenzíven fejlesztenek teszteket, ezek azonban még nem érhetők el a klinikai gyakorlat számára. Jelenleg a kimutatásra arany standard módszer a vírusnukleinsav kimutatása valós idejü PCR-rel. Ennek feltétele a megfelelő módon és tech- 
nikával történő légúti mintavétel (ha ez nem szakszerúen történik, akkor a fertőzőképes személyeket sem detektálják [2]).

Irodalmi adatok alapján a fertőzés kezdete után egy héten belül a betegek <40\%-ánál, 15 nappal utána viszont már 94,3\%-ánál, illetve 79,8\%-ánál jelennek meg a specifikus IgM- és IgG-antitestek a SARS-CoV-2 vírussal szemben [6]. A gyorstesztek ezeket detektálva a fertőzés következtében kialakuló immunválasz kimutatására tehát elvileg alkalmasak lehetnek.

A tesztek fejlesztése, a technológiai problémák, az interferenciát okozó tényezők azonosítása, illetve megfelelő engedélyeztetése, minőség-ellenőrzése összetett és hosszú, esetenként több évig tartó eljárás. A piacra kerülő, Magyarországon aktuálisan beszerezhető, antitest-kimutatáson alapuló, SARS-CoV-2-vírusfertőzést kimutató gyorstesztek esetében erre egyértelmúen nem volt elég idő, az erre vonatkozó adatok rendkívül szegényesek. A tesztekhez mellékelt 1-2 oldalas leírás pontos részleteket nem tartalmaz, nem jelzi például az antitestek esetében a kimutatási értékhatárokat sem.

Munkánkban tapasztalataink alapján értékeltük a gyorstesztek diagnosztikai teljesítményét az elvégzett PCR-vizsgálatok eredményei alapján.

A számolt szenzitivitási és specificitási értékek a vizsgált két teszt esetében gyakorlatilag vállalhatatlanok. Ez a gyakorló klinikus számára azt jelenti, hogy 100 fertőző/fertőzésen átesett betegből az Anhui teszttel 33, a Clungene teszttel 35 személyt lehet azonosítani. Egyben 100 nem fertőző/fertőzésen még át nem esett személyből tévesen érintettséget jeleznek 27, illetve 15 esetben. Ezek az arányok egyértelmúen jelzik, hogy a gyorstesztek a betegség kimutatására, az aktuális fertőző állapot szürésére alkalmatlanok.

A tesztek nagyon alacsony teljesítményjellemző-értékei mögött nem feltétlenül a gyártó alkalmatlansága áll. A vírus replikációs rátája óriási, ennek megfelelően a strukturális plaszticitása miatt nem lehetetlen, hogy a kínai szerológiai kitek részben vagy teljesen más vírusantigéneket tartalmaznak, mint amelyek az európai/hazai fertőzésekben jelen vannak. Ez ahhoz vezethet, hogy az itteni antitestek ezekkel nem vagy nem megfelelően reagálnak, és emiatt ezek az ázsiai gyártmányú tesztek a hazai használatra alkalmatlanok.

Másik lehetőség, hogy az antitestek megjelenéséig eltelt idő hossza a betegek jelentős részénél a 14 napot is elérheti. Ezért érdemes lenne olyan utánkövetéses vizsgálatokat végezni, melyek esetében a PCR-eredmény után 2 héttel is elvégzésre kerülne a gyorstesztvizsgálat.

Egy diagnosztikus teszt által adott információ értékét a szenzitivitás és specificitás mellett alapvetően meghatározza a betegség előfordulási gyakorisága. Ha a betegség lényegében nem fordul elő, a közel 100\%-os szenzitivitású és specificitású tesztek pozitív eredménye is minden esetben álpozitív lesz.

Azt, hogy egy pozitív eredmény milyen valószínűséggel jelez valódi érintettséget az adott populációban, a pozitív prediktív érték (PPV) jelzi. Ez az általunk értékelt tesztek esetében és az általunk észlelt 6\%-os átfertőzöttség (PCR-pozitivitás) mellett 7\%, illetve 13\% körüli volt. Azaz jelenleg 100 Anhui-, illetve Clungene-gyorsteszt-pozitív eredmény közül 7, illetve 13 esetben áll fenn PCR-pozitivitás, vagyis aktuális fertőzőképesség. Ennek alapján ma a gyorstesztek nem alkalmasak a fertőzöttek kimutatására. A pozitív eredmény interpretálása során felvetődő kérdések csak további feszültséget okoznak, illetve anyagi és humánerőforrás-ráfordítást igényelnek.

Azt, hogy egy negatív teszteredmény milyen valószínûséggel jelzi a fertőzöttség hiányát a vizsgált csoportban, a negatív prediktív érték jelzi. Ez az általunk értékelt tesztek esetében 6\%-os átfertőzöttség mellett 95\% körüli. Azaz jelenleg 100 Anhui-, illetve Clungenegyorsteszt-negatív eredmény közül 95 esetben nem áll fenn PCR-pozitivitás. Ezek az értékek akár még magasnak is tûnhetnek, és felvetik, hogy a gyorstesztek helye a diagnosztikában a PCR-negatív status (fertőzésmentesség) jelzése lehet. Azt viszont nem szabad figyelmen kívül hagyni, hogy 6\%-os prevalencia esetén 94\%-os negatív prediktív értéke van annak a tesztnek is, amelyik a csoport minden tagjánál ugyanazt a negatív eredményt adja.

A pozitív és a negatív prediktív értékeket egyértelmüen meghatározza a vizsgált populációban a prevalencia. A prevalencia egyrészt idővel (esetünkben a járvány terjedésével), másrészt a vizsgált populáció megválasztásával, azaz előszűrésével változik. Az utóbbi azt jelenti, hogy ha a gyorsteszttel olyan személyeket vizsgálnak, akiket tünetek, anamnézis, kontaktkutatás kapcsán előszürtek, akkor - mivel esetükben nagyobb a prevalencia - a teszt pozitív prediktív értéke emelhető (például a Clungene teszt esetében akár már 50\%-ra, 30\%-os prevalencia esetén). Kérdéses, hogy ennek van-e értéke a napi klinikai gyakorlatban. Célszerü ezért a kapott eredményt a klinikai adatok, a tünetek és a képalkotó vizsgálatok fényében értékelni. (A nagy rizikójú betegekkel kapcsolatos diagnosztikus kérdéseket lásd itt: [7]).

A gyorstesztek IgM- és IgG-típusú antitesteket egyaránt kimutatnak. Az általános vélekedés az IgG jelenlétét egyértelmúen a védettséghez társítja. Fontos viszont megjegyezni, hogy erre vonatkozóan a gyorsteszt nem ad információt. Csupán kvalitatív értékelést ad, az IgGszintek és az esetleges védőhatás ismerete nélkül. Erre vonatkozóan adatokat olyan tesztek végzésével kaphatunk, melyek az immunglobulinszintek kvantitatív meghatározására lesznek alkalmasak. Ezek várhatóan hamarosan forgalomba is kerülnek [8].

Adataink értékelése kapcsán számos korlátozó tényezőt kell megemlítenünk:

1. A betegek anamnézisére, klinikai állapotára és tüneteire vonatkozóan nem álltak rendelkezésre adatok. Ezért nem lehet megmondani, hogy a gyorsteszt (illetve a PCR-vizsgálat) eredményeivel ezek milyen kapcsolatban lehetnek. A kórtörténet, a PCR- és gyorstesztered- 
mények együttes, követéses vizsgálata lesz szükséges a jövőben annak megválaszolására, hogy melyik teszt pontosan milyen klinikai kérdésre adhat választ.

2. A PCR-pozitivitást a gyorsteszt végzését megelőző vagy azt követő 3 napon belül végzett PCR-teszt eredménye alapján definiáltuk. A gyorsteszteredmény és a PCR-pozitivitás közötti temporális kapcsolat pontos definiálására nem volt elég adatunk.

3. Vizsgálataink nem reprezentatívak az országra. A nálunk észlelt 6\%-os PCR-pozitivitás valószínúleg nagyobb, mint az általános magyar populációban. A vizsgált betegek között döntően a fóvárosi és Pest megyei kórházak és a Semmelweis egyetem dolgozói, betegei és kontaktjai szerepeltek. Ugyanakkor ezzel a kényelmi mintavételezéssel történt elemzésünknek a célja a gyors adatközlés elősegítése volt. Ezért a 2. táblázat az aktuálisan reálisabbnak tünő alacsonyabb prevalencia melletti prediktív értékekre vonatkozóan is ad becslést.

4. A gyorstesztvizsgálatokat szérumból végeztük. Teljes (kapilláris) vérmintára vonatkozóan nincsenek adataink, bár a tesztek leírása szerint ekvivalens eredményt kell(ene) adniuk a kétféle minta esetén.

5. Bár a vizsgálat célja a gyorstesztek és a PCR-eredmények összehasonlítása volt, ettől függetlenül fontos lenne az egyes (individuális) mintáknál kapott értékeket a kétféle gyorsteszt esetében egybevetni. Ez további vizsgálatok tárgya.

\section{Következtetés}

Vizsgálataink eredményét összefoglalva megállapítottuk, hogy a 2020. április elejei becsült, kb. 2\%-os fertőzöttségi prevalencia mellett az általunk vizsgált, magyarországi forgalomba három hete került, COVID-19 IgM/IgG antitestet kimutató gyorstesztek alkalmatlanok a COVID-19-fertőzött, aktuálisan fertőző személyek kimutatására. (Hasonló megfigyelést tett egy olasz munkacsoport a VivaDiag SARS-CoV-2 IgM/IgG gyorsteszt használata során 110 személy bevonásával [9]). Bár a Clungene tesztekkel nagy valószínúséggel utólag ki lehet zárni a korábbi fertőzöttséget, a jelenlegi prevalenciaadatok mellett ennek klinikai értéke kérdéses.

Összességében az általunk értékelt SARS-CoV-2 elleni anti-IgM/IgG-t kimutató, kínai gyártmányú gyorstesztek használatát a mai magyar gyakorlatban a diagnosztikai érték szempontjából nem tekintjük kellően megalapozottnak.

\section{Köszönetnyilvánítás}

A szerzők köszönetüket fejezik ki a PCR-vizsgálatokban és a gyorstesztek végzésében részt vevő önkénteseknek és a Laboratóriumi Medicina Intézet munkatársainak.
Anyagi támogatás: A közlemény megírása anyagi támogatásban nem részesült.

Szerzői munkamegosztás: V. B.: A vizsgálat megtervezése, adatelemzés, a közlemény megírása, klinikai következtetések. K. K., Sz. D., O. E.: Vizsgálatok végzése, a közlemény kijavítása, klinikai következtetések. P. Z.: Vizsgálatok végzése, adatelemzés, a közlemény kijavítása, klinikai következtetések. M. B.: A közlemény kijavítása, klinikai következtetések. A cikk végleges változatát valamennyi szerző elolvasta és jóváhagyta.

Érdekeltségek: A szerzőknek nincsenek érdekeltségeik.

\section{Irodalom}

[1] Váradi A, Ferenci T, Falus A. The coronavirus-induced COVID-19 pandemic. Previous experiences and scientific evidences at the end of March, 2020. [A koronavírus okozta COVID-19-pandémia. Korábbi tapasztalatok és tudományos evidenciák 2020. március végén.] Orv Hetil. 2020; 161: 644651. [Hungarian]

[2] Lippi G, Simundic AM, Plebani M. Potential preanalytical and analytical vulnerabilities in the laboratory diagnosis of coronavirus disease 2019 (COVID-19). Clin Chem Lab Med. 2020 Mar 16. Doi: 10.1515/cclm-2020-0285. [Epub ahead in print]

[3] Loeffelholz MJ, Tang YW. Laboratory diagnosis of emerging human coronavirus infections - the state of the art. Emerg Microbes Infect. 2020; 9: 747-756.

[4] Jacobs J. Guidance on the use of COVID-19 rapid diagnostic tests. Available from: https://www.itg.be/E/Article/guidanceon-the-use-of-covid-19-rapid-diagnostic-tests [accessed: April 17,2020 .]

[5] Diagnostic test evaluation calculator. MedCalc Software Ltd., Ostend, 2020. Available from: https://www.medcalc.org/calc/ diagnostic_test.php [accessed: April 17, 2020.]

[6] Zhao J, Yuan Q, Wang H, et al. Antibody responses to SARSCoV-2 in patients of novel coronavirus disease 2019. Clin Infect Dis. 2020 Mar 28. Doi: 10.1093/cid/ciaa344. [Epub ahead in print]

[7] Korsós A, Kupcsulik Sz, Lovas A, et al. Diagnostic consideration and bedside estimation of the prognosis in COVID-19 patients. [Diagnosztikus lépések és a betegség prognózisának a becslése COVID-19-fertőzött betegeken.] Orv Hetil. 2020; 161; 667671. [Hungarian]

[8] Vashist SK. In vitro diagnostic assays for COVID-19: recent advances and emerging trends. Diagnostics (Basel) 2020; 10: 202. Doi: 10.3390/diagnostics10040202.

[9] Cassaniti I, Novazzi F, Giardina F, et al. Performance of VivaDiag COVID-19 IgM/IgG rapid test is inadequate for diagnosis of COVID-19 in acute patients referring to emergency room department. J Med Virol. 2020 Mar 30. Doi: 10.1002/ jmv.25800. [Epub ahead in print]

(Vásárhelyi Barna dr., Budapest, Nagyvárad tér 4., 1089 e-mail: vasarhelyi.barna@med.semmelweis-univ.hu) 